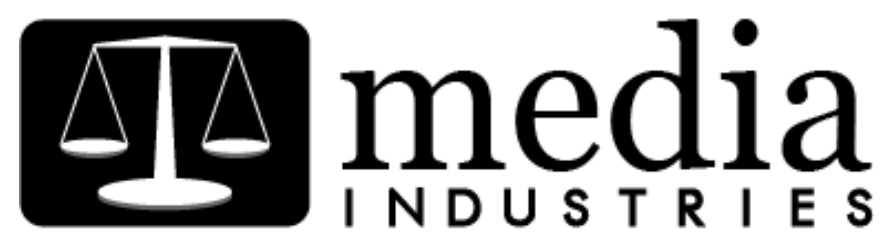

\title{
Media Policy Research and the Media Industries
}

\section{Des Freedman 1}

\author{
Goldsmiths, University of London \\ d.freedman [AT] gold.ac.uk
}

\begin{abstract}
:
This essay highlights the need for a critical approach to policy as a key feature of media industries research. All too often media policy is understood and investigated as an administrative procedure that appears to be remote from the more dazzling world of media production and consumption, and of texts and audiences. This essay argues that issues of creativity and practice should not be insulated from analysis of the structural contexts of media environments. It also argues that media policy research itself needs to expand its horizons to include the full range of actors and venues-unofficial as well as official-in which decisions about the distribution of media resources are made. A critical media policy should focus on the interests mobilized and values expressed in relation to different policy areas by situating policy debates in relation to the dynamics of power that circumscribe the institutions, individuals, products, and possibilities of the media industries.
\end{abstract}

Keywords: Policy, Political Economy, Regulation

How the media industries "work" is connected to how they are structured in relation to the various policy frameworks to which they are exposed. In order to fathom the dynamics of these industries, therefore, one of our tasks is to research media policy environments and pressures. And yet there is a problem, based in part on reputation and in part on conception. All too often, media policy research is viewed as not just a poor relative of more exciting media industries research but rather the boring next-door neighbor who spends too long at your house, convinced that he has lots of interesting things to say while everyone else makes polite excuses and tries to usher him out.

There is good reason for this. Both media policy and media policy research are frequently reduced to the drawing up of rules and regulations, of laws and liabilities, rather than the setting of boundaries within which these interventions are devised and implemented. Furthermore, media policy lacks the participatory edge of other areas of media production and consumption: it does not have fans or celebrities or the seductive powers of actors and special effects; it lacks exoticism and is "marginal" only to the extent that it appears to be indifferent to everyday life; it lacks transparency and accessibility; and it marginalizes agency. Of course there are media policy "actors" but they are remote and "expert": civil servants, ministers, 
special advisers, lobbyists, moguls, executives, technologists, entrepreneurs, and the odd academic. Media policy has a particularly pragmatic and positivist character and is understood (and often researched) in terms of political bargaining processes rather than creative practice. Policies exist on pieces of paper, they are written in arcane parliamentary language, and they are to be applied and expected to achieve measurable effects. They are tangible, rational, necessary prescriptions for a healthy media ecology.

Most of the time media policy appears to work this way and most of the time, many (though certainly not all) media policy researchers are implicated in this process. We provide the evidence, turn up at the seminars, produce the submissions, and bid for the research projects. We participate in a system over which we have little control but a great desire to make work better-more efficiently, more rationally and, perhaps, more democratically.

What is the problem with this approach? First, this account of policy reminds me of Stephen Lukes's description of the first "face" of power which is all about the visible jostling for advantage in any bargaining process. ${ }^{2}$ Think back to Robert Dahl's study of the political system of New Haven, Connecticut, Who Governs?,3 where politics is dominated by coalitions, rival groups of actors and interests, none of whom could be said to exercise complete control. This is a form of pluralist politics that, according to Dahl, is notable for its "dispersion of political resources," the "disappearance of elite rule," and the emergence of polyarchy, which Dahl saw ultimately as a benign mode of democratic politics. ${ }^{4}$

But this is not how I understand media policy, which I see not simply as conflictual, but rather a fundamentally distorted process where rival interests interact in unequal conditions in order to shape the dynamics of the media environment and to lay the preconditions for the production, circulation, and consumption of media goods. This means that we need to look at ideologies as well as institutions, power as well as paperwork, elites as well as evidence. As Matthias Kunzler argues, we need a "force of ideas approach" to think about the values espoused by leading actors in the policy process and how these then have an impact on the design and institutionalization of different approaches to the media world. ${ }^{5}$ Given the domination of neoliberal conceptions of market value and private property together with the tensions apparent across the world in relation to issues of media ownership, surveillance, freedom of expression, and representation, I hardly need to spell out that there is a lot more to media policymaking than the happy pluralism with which it is often associated by those "inside the circle," particularly in places like the US and the UK.

It also means that it is vital not to insulate questions of policy from those of content and creative practice and from the spaces of media institutions and flows. The artificial separation between policy and media production and consumption weakens our understanding of media industries. The aesthetic strategies, creative endeavors, and forms of resistance that may or may not be present in popular, everyday communication are critically related to the wider structural contexts of media environments in which certain types of behavior and certain political preferences are rewarded or marginalized. The ability to not only talk "truth to power" but to represent the voices of ordinary people, to speak in dialect, to open up conversations that others do not want to open up, to reflect the way a society is headed-all these are constrained by the policy choices debated and enacted in any contemporary mediated society. Media policy matters so much precisely because it relates to an increasingly central part of the way in which governments everywhere seek to legitimize themselves - through management and control of 
the means of communication - and in which citizens seek to navigate the world in which we live.

Of course, media policy is not simply about elite news management but about wider processes of social reproduction seen as the terms on which society represents itself and holds itself accountable. It is about who is allowed to speak on social media, in the press, on television, and how the conversations are structured. Media policy shapes and is shaped by contextual factors: Are media industries designed to make money for advertisers, to massage the ego of a particular administration, or to help produce informed, active, independently-minded citizens? What are the connections between state elites and media elites? What are the labor and speech conditions under which media professionals are able to work? Media policies help to structure these outcomes and we should not allow its research orientation to be reduced, as it often is, either to administrative procedure or to technological multiple choice.

We need, therefore, to treat media policy a bit more like a production study, to investigate as Mayer et al. put it, "the complexity of routines and rituals, the routines of seemingly complex processes, the economic and political forces that shape roles, technologies, and the distribution of resources according to cultural and demographic differences." 6 Above all, we need to engage with questions of power in terms of the distribution of resources that are concentrated inside the media and the struggles for the redistribution of those resources.

My second thought is about what happens when media policy breaks out of its institutional location-when it moves from the private dining and meeting rooms, from the palaces and parliaments, into public arenas and, sometimes even, onto the streets. This has happened in a whole number of places in recent years, including in Mexico City with the Yo Soy 132 movement protesting the duopoly of Televisa and TV Azteca; in Athens following the shutdown of the Greek public service broadcaster; in Istanbul where protestors gathered outside private TV stations complaining about the refusal by mainstream TV to cover the attacks on peaceful demonstrators in Taksim Gezi Park; and in the US, where there were protests in at least twelve cities against the takeover of local newspapers by the politically and socially conservative Koch Brothers.

Perhaps these protests were simply responses to undesirable media policies: bad ones, misguided ones, or "nonexistent" ones.7 But I want to argue that these protests constitute a central element of the policy process: the public contestation of the terms on which policies are conceptualized and debated. This is what I call public participation in the policy process, even though it is usually bad-tempered, not within the guidelines of the usual methods for taking part, not couched in particularly parliamentary language, and sometimes not even using the language of media policy at all. Nevertheless, this is living, breathing media policy and it should be taken just as seriously as the formal submissions to a parliamentary select committee. More significantly for this journal, these protests matter because they ask fundamental questions about the conditions under which creative practices take place (or are prevented from taking place).

In these circumstances, we need an approach to media policy that is ideological as opposed to administrative, political as opposed to partisan, interested as opposed to disinterested, and committed to principles of social justice rather than serving the interests of either state or private elites in their pursuit of "efficiencies" and control. When we consider how best to respond to controversies concerning ownership, net neutrality, press freedom, copyright, labor 
relations - all of them phenomena that condition the dynamics and the possibilities of the media industries - we need to think of policy as both an empirical fact and an ideological tool. Indeed, media policy in particular is becoming increasingly contested as the resources needed to govern and control media are becoming increasingly intertwined with processes of mediation.

If media policy is to be made meaningful, inclusive, and democratic, then it will have to be dragged, kicking and screaming, from the corridors of power and into the public domain. The same goes for media policy research that can illuminate the wider mechanisms of power that underpin the performance and possibilities of media industries. We need a research agenda for the media industries that examines not just performative routines and creative rituals, not just the allocation of resources and the mechanisms of representation, but the power relations that are brought to bear in shaping the policy contexts that underlie these phenomena. If we do so, perhaps more people will then invite us 'round to dinner.

${ }^{1}$ Des Freedman is Professor of Media and Communications in the Department of Media and Communications at Goldsmiths, University of London. He is the author of The Politics of Media Policy (Polity, 2008), co-author with James Curran and Natalie Fenton of Misunderstanding the Internet (Routledge, 2012) and an editor of the journal Global Media and Communication. He is the current chair of the Media Reform Coalition and his new book, The Contradictions of Media Power (Bloomsbury) will be released in fall 2014.

2 Steven Lukes, Power: A Radical View (Basingstoke: Palgrave Macmillan, 2005 [1974]).

3 Robert Dahl, Who Governs? Democracy and Power in an American City (London: Yale University Press, 2005 [1961]).

${ }^{4}$ Dahl, Who Governs?, 85-86.

${ }^{5}$ Matthias Kunzler, "'It's the Idea, Stupid!' How Ideas Challenge Broadcasting Liberalization," in Trends in Communication Policy Research, eds. Natascha Just and Manuel Puppis (Bristol: Intellect, 2012), 57.

6 Vicki Mayer, Miranda Banks, and John Thornton Caldwell, "Introduction: Production Studies: Roots and Routes," in Production Studies: Cultural Studies of Media Industries, eds. Vicki Mayer, Miranda Banks, and John Thornton Caldwell (New York: Routledge, 2009), 4.

7 Des Freedman, "Media Policy Silences: The Hidden Face of Communications Decisionmaking," International Journal of Press/Politics 15, no. 3 (2010): 344-61.

\section{Bibliography}

Dahl, Robert. Who Governs? Democracy and Power in an American City. London: Yale University Press, 2005 [1961].

Freedman, Des. "Media Policy Silences: The Hidden Face of Communications Decisionmaking." International Journal of Press/Politics 15, no. 3 (2010): 344-61.

Kunzler, Matthias. “'It's the Idea, Stupid!' How Ideas Challenge Broadcasting Liberalization.” In Trends in Communication Policy Research, edited by Natascha Just and Manuel Puppis 55-74. Bristol: Intellect, 2012.

Lukes, Steven. Power: A Radical View. Basingstoke: Palgrave Macmillan, 2005 [1974]. 
Mayer, Vicki, Miranda Banks, and John Thornton Caldwell, “Introduction: Production Studies: Roots and Routes." In Production Studies: Cultural Studies of Media Industries, edited by Vicki Mayer, Miranda Banks, and John Thornton Caldwell. 1-12. New York: Routledge, 2009.

\section{(c) $\mathrm{BY}-\mathrm{NC}-\mathrm{ND}$}

Copyright (c) 2014 (Des Freedman). Media Industries is and open-access, peer-reviewed, online academic journal. As such, we aim to participate in the open exchange of information. This work is licensed under a Creative Commons Attribution Noncommercial No Derivatives (by-nc-nd) License. Under this license, this work is available for sharing and noncommercial distribution provided the appropriate attribution is given. 